interests in polar activities and polar literature. Scott and Amundsen will likewise upset many readers, not only in Britain but abroad. This is a pity as it contains much material that is new and useful. Given the same sympathetic understanding of Scott against the background of his day and his career, as the author showed with Amundsen, the book could have made a valuable contribution to our understanding of that era of polar exploration and research.

This reviewer is also out of sympathy with the author's interpretation of the background events and values. To describe the British Empire of 1868-1912 as in decline, and Scott as symbolic of this decline seems unreal. Similarly the author's values are revealed by his description of his heroes-Amundsen, Bjaaland and Oates-as nature's (or natural) aristocrats, while Scott is damned as middle class, and a mere dog driver is described as a mulish Russian peasant.

The book is out of step with the present international spirit of Antarctic research which is based on realistic mutual appreciation between expeditions. It is a spirit that is wider than national pride in the early Antarctic expeditions. The achievements of the US naval expeditions under Wilkes, for example, are more widely acknowledged in Europe for their contribution to mapping and research than was the case two decades ago.

For a balanced view of the merits of some Antarctic leaders of Scott's time, we can turn to Sir Raymond Priestley, who served both Shackleton and Scott and very briefly met Amundsen in mid-career. In his presidential address to the British Association in 1956 he says: 'I believe a colleague hit the nail when he wrote: "as a scientific leader give me Scott; for swift and efficient polar travel, Amundsen; but when things are hopeless and there seems no way out, get down on your knees and pray for Shackleton." '

Perhaps by debunking Scott, Huntford has given him the ultimate accolade. Such treatment in these days seems to be reserved for our greatest national figures.

\title{
THE CIRCUMPOLAR NORTH
}

[Review by Trevor Lloyd* of The circumpolar north by Terence Armstrong, George Rogers and

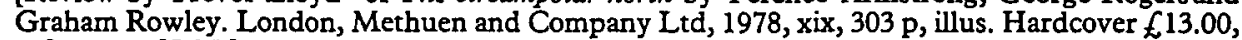
soft cover $£ 5.95$.]

With the current wealth of information on northern polar regions, the authors of The circumpolar north made the wise decision to restrict themselves to 'political and economic affairs with some environmental background'. Designed 'for everyone with a more than superficial interest in the northern regions of our planet', the book is primarily aimed at the student of northern affairs. The introduction delimits the area treated, underlines its importance and then provides a concise and well-written description of the geographical background. Two chapters at the end of the book also review the circumpolar areas as a whole concentrating on international conflict and co-operation', and 'world affairs'. The body of the book is divided into five regional chapters which deal with 'Northern USSR: the north in a socialist economy'; 'Canada: the slow retreat of "the north" '; 'Alaska: the evolution of a northern polity'; and 'The north of the Old World: lands of the northeast Atlantic'. There are in addition reference sections and statistical appendices of particular value to student readers. Of the 22 maps, those which depict the circumpolar north as a whole or the larger regions have suffered considerably from reduction, but others, for example, the detailed map of recent oil and gas fields and pipelines in the west Siberian plain, are invaluable. Good maps and recent statistics are of course essential, and the preparation of an atlas and statistical handbook of the circumpolar north as a companion to the present volume, may be worth consideration.

There are 37 tables printed within the text and many of them might better have appeared as appendices, where up-dating of statistical data or later editions would have been simpler.

Although the subject matter of the regional chapters follows the same general plan, the authors have not been confined to a single rigid scheme. Because of this, they have been free to emphasize special features of each region. The chapter on the northern USSR will be used to indicate the

* Association of Canadian Universities for Northern Studies, 130 Albert, Suite 1208, Ottawa, Canada KIP SG4. 
general plan. It opens with a concise description of the geographical and historical background, followed by a summary of resources and their development, including reference to towns and settlements. The chapter continues with a formal treatment of population and the labour force, including a useful discussion of the nationalities of the far north, particularly in relation to the incoming Russians. The section on government and administration points out the absence of any unifying administrative arrangements for the Soviet north. Transportation is particularly well described and also includes a detailed list of icebreakers used on the Northern Sea Route in 1976. A concluding section entitled 'National significance' places the Soviet north in perspective within the Soviet Union and concludes: '.. it is clear that the North is very important to the USSR, economically and strategically, and ... the investment in it is such that its importance is unlikely to diminish'.

Northern Canada is treated in much the same way, but with a useful additional section summarizing the status of the region at the outbreak of World War II. This provides a baseline from which to assess the extensive changes which have taken place in the past 40 years. While the discussion of resources includes extended comment on petroleum, it might have been useful to emphasize that production of oil and gas in northern Canada has so far been negligible in comparison with Alaska and the Soviet north. There are interesting sections on native land claims and environmental issues, and on administrative and social conditions. However, no reference is made to the significant absence in northern Canada of the type of systematic planning followed in the northern USSR. The story of Alaska seems to be quite different. The 'evolution of northern polity' is demonstrated clearly with emphasis on economic forces, the interests of the well-organized white settlers and the influence of native groups. Interestingly, defence has been a major economic factor in Alaska's advancement-as it no doubt has been in the Soviet north-though the book makes little or no mention of this.

The chapter on Greenland was written while the country's political future was under discussion, so not unexpectedly 'home 'rule' occupies more space than it would have done a decade ago. The evolution of economic and political affairs is well described, though with little of the customary praise for Danish policies in comparison with those followed during the same period in northern Canada, northern Russia and in Alaska. It is, however, mentioned that during the 175 years of the Danish trading monopoly, the guiding principle was that the welfare of the Eskimos should receive the highest possible consideration, even over-riding where necessary the interests of trade. The north of the Old World, which includes Norway, Sweden, Finland and Iceland, with some reference to Svalbard, the Faeroe and Jan Mayen islands is adequately covered.

All in all the authors deserve our thanks and congratulations for providing in a little over 300 pages a detailed, contemporary, well-planned and highly readable study of the regions of the Arctic and sub-Arctic. The book will be of particular value to the increasing number of students taking courses in the study of northern lands.

\section{THE LEGAL STATUS OF THE NORTHERN SEA ROUTE}

[Review by William Barr* of William E. Butler's Northeast Arctic passage, Alphen aan den Rijn, Sijthoff and Noordhoff, 1978, xii, 199 p, illus.]

Professor Butler's book is the first of a series of volumes on the legal status of the international straits of the world edited by the Center of Marine Policy at the University of Delaware. The choice of Professor Butler as the author of this particular volume, which deals with the straits and seas of the Soviet Arctic, is a felicitous one; he is an internationally recognized expert on Soviet legal attitudes to various aspects of navigation and the law of the sea.

The timing of the work is also opportune. The attainment of the North Pole by the Soviet icebreaker Arktika in August 1977, the May-June 1978 voyage by the icebreaker Sibir' and ice-strengthened freighter Kapitan Myshevskiy from Murmansk to Bering Strait by a route north of Novaya Zemlya, Severnaya Zemlya and Novosibirskiye Ostrova, and the maiden voyage of the Canadian icebreaking bulk carrier Arctic all indicate that a new era of more intense international

* Department of Geography, University of Saskatchewan, Saskatoon, Saskatchewan S7N 0 WO. 